\title{
Rain water use efficiency of sweet potato under cattle-cud mulches in Uyo, Nigeria
}

\begin{abstract}
Rain Water Use Efficiency (RWUE) of sweet potato under cattle-cud mulches was investigated with the aim of identifying appropriate cattle-cud mulch rates for managing the fragile soils of the humid tropics to ensure sustained productivity of sweet potato. Experimental units measuring $9 \mathrm{~m}^{2}$ each were used and sweet potato vines were planted at the spacing of $1 \times 0.5 \mathrm{~m}^{2}$. Cattle-cud mulches at rates of $\mathrm{M}_{0}, \mathrm{M}_{10}, \mathrm{M}_{20}$ and $\mathrm{M}_{30}$ tons ha ${ }^{-1}$ were administered to the different plots. Yield parameters of sweet potatoes as well as rainfall data for the period were collected. Data were assessed using the Analysis of Variance and correlation analyses were also performed to determine the relationships between soil and crop parameters. Results showed that RWUE of 2.38 from $\mathrm{M}_{30}$ plot was significantly higher than other treatments. This correlated with significantly $(P<0.05)$ high tuber girth $(19.0 \mathrm{~cm})$, tuber length $(21.0 \mathrm{~cm})$, marketable size $(32.33 \mathrm{~cm})$ and number of tuber yield $(60.50)$. Also, organic matter content of the soil receiving $M_{10}(3.60 \%)$ and $M_{20}(3.04 \%)$ cattlecud mulches were significantly higher than $\mathrm{M}_{0}(2.96 \%)$. The use of cattle-cud as a mulch material significantly increased RWUE and also improved the yield and yield component of sweet potato.
\end{abstract}

Keywords: RWUE, mulches, cattle-cud, fragile soil, tuber yield
Volume 6 Issue 3 - 2021

\author{
ID Edem,' PI Udounang, ${ }^{2}$ PC Ama' \\ 'Department of Soil Science and Land Resources Management, \\ Faculty of Agriculture, University of Uyo, Nigeria \\ ${ }^{2}$ Department of Crop, Faculty of Agriculture, Akwa lbom State \\ University, Nigeria
}

\begin{abstract}
Correspondence: ID Edem, Department of Soil Science and Land Resources Management, Faculty of Agriculture, University of Uyo, Bag 1017, Uyo, Nigeria, Tel +234-80-27031426,
\end{abstract} Email dennis.edem@gmail.com

Received: November 22, 2020 | Published: June 10, 2021

\section{Introduction}

Roots and tubers, most notably cassava, sweet potato, yam and Irish potatoes (Solanum tuberosum) are some of the most important primary crops. ${ }^{1}$ Sweet potatoes production is a very important industry throughout the world. Among the tuber crops grown in the world, sweet potato ranks second after cassava. ${ }^{2}$ According to the United States Department of Agriculture statistics, ${ }^{3}$ over 135 million tons of sweet potatoes were produced in 2002. China is the world leader in sweet potato production with over 113 million tons produced which represents roughly $83 \%$ of the world's sweet potato production. The next closest countries in sweet potato production are Nigeria and Uganda with 2.6 million tons. ${ }^{4}$ The area under sweet potato production in Nigeria is estimated at about 204.7 million hectares of land with 2.516 million metric tonnes in 2005 and 3.462 million metric tonnes in $2006.5,6$

Sweet potato (Ipomea batatas L.) is a eudicotyledonous warm season crop, which belongs to the Convolvulaceae or morning glory family. It is an herbaceous plant with creeping perennial vines and adventitious roots. Sweet potato is used for human consumption, livestock feed and for industrial processing. The crop has several industrial uses, including medicinal purposes; use for the treatment of ulcer, diabetes, hookworm and internal bleeding. ${ }^{7}$ If given the right growing conditions, sweet potato has the potential to produce remarkably high yields and can also yield more reliably under unfavourable conditions than many other crops. This is why it is so important for household food security in many places in Sub-Saharan Africa. ${ }^{8}$ Moisture is very important in the growth of Sweet potato. During cultivation, it is important to have moist soils in order to achieve good germination. ${ }^{9}$ A well distributed rainfall of $75-150 \mathrm{~cm}$ is sufficient for its cultivation; it can tolerate drought to some extent but cannot withstand water logging. ${ }^{10}$

To improve sustainability of agriculture, high yielding crop varieties with improved Water Use Efficiency (WUE) are needed. ${ }^{11}$
Grains Research and Development Coperation (GRDC) ${ }^{12}$ defined Water Use Efficiency (WUE) as the measure of a cropping system's capacity to convert water into plant biomass or grain. It includes both the use of water stored in the soil and rainfall during the growing season. According to Hartfield and Dold ${ }^{13}$ Water use efficiency (WUE) is defined as the amount of carbon assimilated as biomass or grain produced per unit of water used by the crop. It relies on: the soil's ability to capture and store water; the crop's ability to access water stored in the soil and rainfall during the season; the crop's ability to convert water into biomass; and the crop's ability to convert biomass into grain (harvest index). ${ }^{12}$

Kar and Kurma ${ }^{14}$ in their study to investigate the effects of irrigation and straw mulch on water use and tuber yield of potato in eastern India observed that higher yield and better crop growth were observed in the mulched plots, which might be due to conservation of soil moisture and reduction of soil temperature by $4-6^{\circ} \mathrm{C}$. They recommended that three irrigations of $75 \mathrm{~mm}$ each and mulching should be used for growing potato in the region when limited water was available.

Surface mulch is an important factor of soil protection technology in the cultivation of potatoes. ${ }^{15}$ Mulch is any covering material including either organic or inorganic applied on the soil surface to reduce evaporation losses. ${ }^{16}$ To the researchers, this material may be grown and maintained in place, or any material grown and modified before placement or any material processed or manufactured and transported before placement. Among other benefits, organic mulch conserves soil moisture by reducing water lost through evaporation, minimizes soil erosion, moderates soil temperatures and encourages the growth of beneficial soil microorganisms. ${ }^{16}$ The organic mulch used for this study was the cattle-cud. This is the feed in the rumen of cattle. The rumen which contains billions of bacteria, protozoa, molds, and yeasts, ${ }^{17}$ ferments the feed and make volatile fatty acids, $\mathrm{B}$ vitamins, vitamin $\mathrm{K}$ and amino acids $^{18}$ making the material more dense with nutrients. 
Khan et al. ${ }^{19}$ concluded that mulch addition increased the total porosity in more compacted soil under reduced tillage. According to $\mathrm{Lal}^{20}$ the judicious use of tillage practices overcomes edaphic constraints, whereas inopportune tillage may cause a variety of undesirable outcomes, such as soil structure destruction, accelerated erosion, loss of organic matter and fertility, and disruption in cycles of water, organic carbon, and plant nutrient. The data on tillage systems are needed to identify appropriate tillage methods for managing the fragile soils of the humid tropics to ensure sustained productivity. ${ }^{2}$

The use of cattle-cud as mulching materials for sweet potato production has not received adequate research attention in southeast Nigeria. Hence the study sought to investigate the rain water use efficiency of sweet potato under different cattle-cud mulches in Uyo.

\section{Materials and methods}

\section{Study area}

The study was conducted in Uyo in Akwa Ibom state, south eastern Nigeria which lies between latitude $04^{0} 32^{1}$ and $05^{0} 33^{1}$ north and longitude $07^{0} 25^{1}$ and $08^{0} 25^{1}$ east. The state has two seasons; the wet and dry seasons and the rainfall pattern is bimodal, with rainfall beginning in about early March and ends around mid-November.
Uyo has a mean annual rainfall of about $2484 \mathrm{~mm}$, mean annual temperature of $27^{\circ} \mathrm{C}$, with varying relative humidity through the year from $70-80 \% .{ }^{22}$ The state is underlain by one geological formation, the coastal plain sands comprising largely poorly consolidated sands. ${ }^{23}$ The climatic factors favour luxuriant tropical rainforest and land use practices predominating in the area include forest plantation, tree crop plantation, swamp rice and intensive upland cultivation with a great variety of crops grown such cassava, yam, maize, fluted pumpkin and cocoyam.

\section{Procurement of materials}

Core and bulk soil samples were randomly taken at depth 0 to $15 \mathrm{~cm}$ based on plots from the experimental sites during pre and post planting stages. Hybrid sweet potato (TIS 87/0087) vines were obtained from the Research Centre in Michael Okpara University of Agriculture, Umudike. Cattle-cud digester was collected from Ntak Inyang Abbatoir and dried to $12 \%$ moisture content (Figure 1) and weighed for application rates of 10, 20 and 30ton/ha treatments. Rainfall data during the planting period was obtained from the University of Uyo weather station. At harvest, the tuber length, tuber girth, number of tubers and yield were measured.

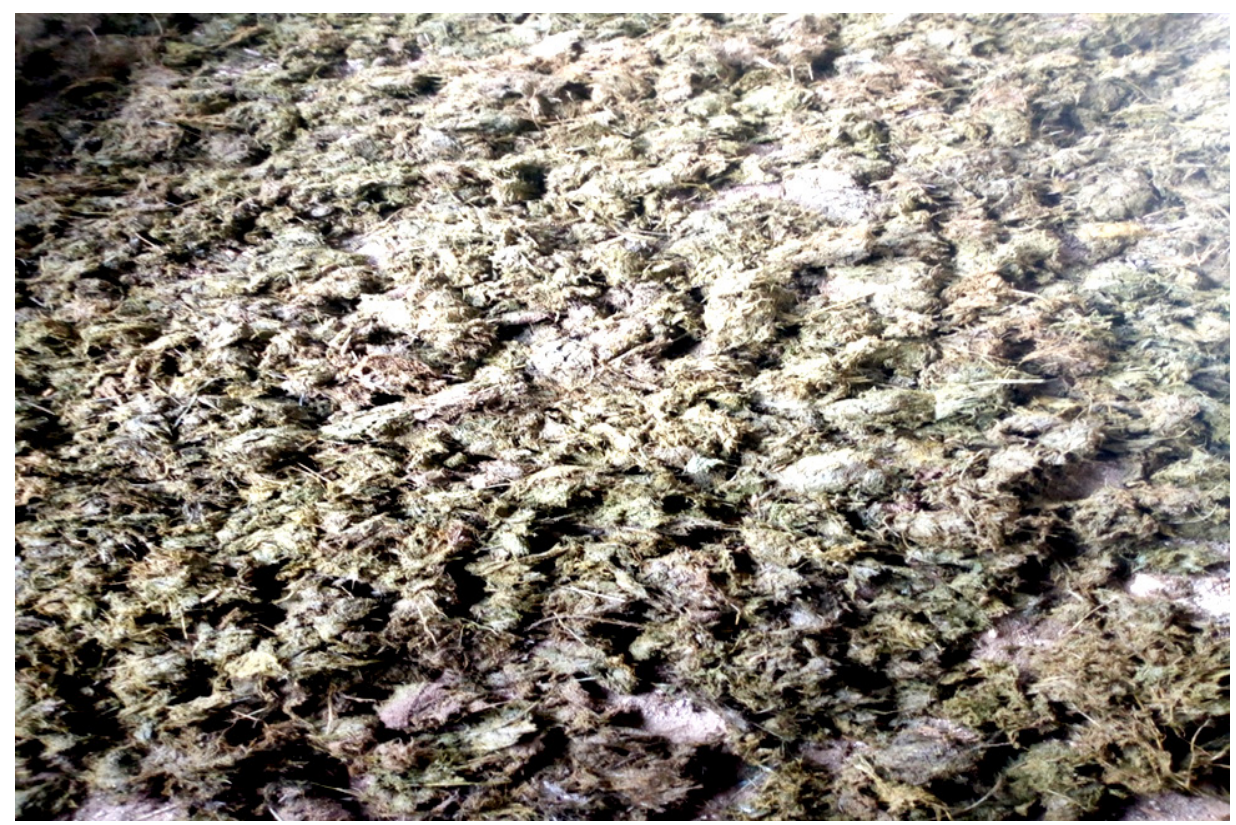

Figure I Cured cattle cud digester to be applied on sweet potato field.

\section{Field experiment}

The experimental plots were cleared manually, mapped out employing a split plot using randomized complete block design with three replications. Two tillage practices (conventional and notillage) were established and four rates of cattle cud digester $(0,10$, 20 and 30 tons ha ${ }^{-1}$ ) were used giving eight treatment combination. Each experimental unit measured $9 \mathrm{~m}^{2}$ and a vine measuring $25 \mathrm{~cm}$ was planted per stand at the spacing of $1 \mathrm{mx} 0.5 \mathrm{~m}$, giving a total of 18 plants per plot. The cured cattle-cud mulch was applied one week after planting (Figure 2).

\section{Analytical methods}

Core samples collected from the experimental units were used for determining hydraulic conductivity and bulk density. The constant head permeameter method as described by Klute and Dirksen ${ }^{24}$ was used for determining hydraulic conductivity while bulk density was done using Gulser and Candemir ${ }^{25}$ method. Aggregate analysis was done using the wet sieve method; Soil $\mathrm{pH}$ and electrical conductivity were measured in 1:2.5 soil and water ratio using a digital $\mathrm{pH}$ meter $^{26}$ and conductivity bridge, ${ }^{27}$ respectively. Organic carbon was determined using Walkley and Black wet oxidation method ${ }^{28}$ Organic Total nitrogen was determined using micro kjeldahl digestion and distillation method. ${ }^{29}$

Available phosphorus was extracted by Bray p-1 method of Bray and Kurtz as described by $\mathrm{Kuo}^{30}$ and phosphorus in the extract was obtained by blue colour method of Murphy and Riley. ${ }^{31}$ Exchangeable bases were extracted using $1 \mathrm{~N}$ ammonium acetate and the solution was used for the determination of calcium and magnesium through 
EDTA (Ethylene diamine tetra acetic acid) titration as well as sodium and potassium measured by flame photometer. Exchangeable acidity was extracted with one normal potassium chloride solution (1NKCL) and acidity determined by titration as described by Thomas. ${ }^{32}$

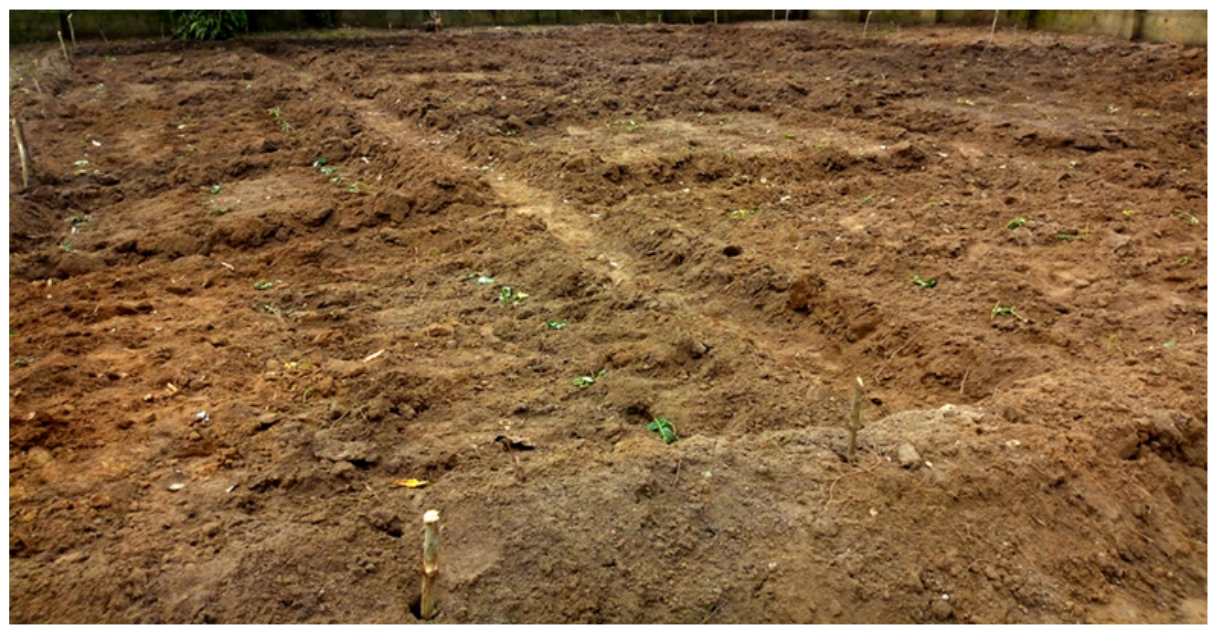

Figure 2 Field layout with newly planted potato vine in strips.

Rain Water Use Efficiency (RWUE) was calculated using the formula below;

$$
\mathrm{RWUE}=\frac{\text { Yield }(\mathrm{kg})}{\mathrm{RF}}
$$

Where, RF - Rainfall received from planting to maturity of crop

Nutrients Enrichment in the were determined and converted to $\mathrm{kg} \mathrm{ha}^{-1}$ using the methods described by Karle and Stott. ${ }^{33}$ Plant nutrients losses due to rain water erosion were evaluated with nutrient enrichment ratio (ER).

$$
\text { ER was defined as; } \mathrm{ER}=\mathrm{Ce} / \mathrm{Co} \text {. }
$$

Where $\mathrm{Ce}$ is the nutrient concentration in plots and Co is the nutrient concentration of control soil at $0-5 \mathrm{~cm}$ depth. The nutrient ratio of $\mathrm{N}, \mathrm{P}, \mathrm{Ca} \mathrm{Mg}$ and $\mathrm{K}$, in the treated was computed as described by Cogle et al. ${ }^{34}$

\section{Soil loss determination}

The soils collected from the peel of the tuber during harvest for each plot were washed; oven dried and weighed in grams. Soil and nutrient losses were estimated as proposed by Ruysschaert et al. (2014).

Total soil loss due to crop harvesting will be calculated using:

$$
\mathrm{SLCH}_{\text {spec }}\left(\mathrm{kgkg}^{-1}\right)=\frac{M d s-M r}{\text { Mcrop }}
$$

Where, Mds = Mass of dry soil $(\mathrm{kg})$

$\mathrm{Mr}=$ Mass of rock fragments $(\mathrm{kg})$

Mcrop $=$ Net crop mass $(\mathrm{kg})$

Total soil loss due to crop harvesting for a given treatment will be calculated using:

$$
\mathrm{SLCH}_{\text {crop }}\left(\mathrm{Kgha}^{-1} \text { harvest }^{-1}\right)=\mathrm{SLCH}_{\text {spec }} \times \mathrm{TY}
$$

Where TY $=$ tuber yield

\section{Nutrient loss determination}

The samples for soil loss will be analysed for the essential nutrients using recommended listed above in section above and results will be used to calculate nutrient loss during harvest using:

Nutrient Loss $\left(\right.$ Kgha $^{-1}$ harvest $\left.^{-1}\right)=\frac{\text { Nutrients }(g)}{\operatorname{Soil}(100 g)} \times \frac{1}{100} \times \operatorname{SLCH}_{\text {spec EQU } 5}$

\section{Statistical analysis}

Data obtained in the study were subjected to Analysis of Variance (ANOVA) using GenStat (Discovery edition 3) statistical software. Significant means were separated by Duncan Multiple range test (DMRT) at $5 \%$ probability level. Correlation analysis was used to evaluate the relationship between soil properties and yield data.

\section{Results and discussion}

\section{Effect of different tillage practices and rates of cattle- cud digester on some soil physical and chemical properties}

Soil texture: The texture of the soils before planting was loamy sand and remained unchanged throughout the planting season (Table 1). The experimental soils were dominated by sand particles, with values ranging from 79 to $80 \%$ at the pre-planting stage, 79 to $83 \%$ at the mid-planting stage and 85 to $87 \%$ at the harvest whereas the content of clay and silt particles were lower. The different tillage methods and rates of cud-mulch treatments did not significantly affect the soil particle sizes. According to Omenihu and Opara-Nadi, ${ }^{35}$ soil particle size distribution, which constitutes texture is an inherent soil property and is not affected by soil management.

Bulk density and porosity: The different rates of Cattle-cud mulch showed statistically similar bulk densities and total porosities at the two stages of soil study (Table 1), though apparently, highest bulk densities were recorded with $\mathrm{M}_{0}$ with decreases in bulk densities being observed as the rate of mulch application increased. Tillage significantly affected the bulk density at the pre-plant stage with 
the bulk density of TL soil $\left(1.06 \mathrm{Mgm}^{-3}\right)$ being significantly higher than that of NT soil $\left(0.95 \mathrm{Mgm}^{-3}\right)$ (Table 1). Consequently, the total porosity for NT soil $(63.84 \%)$ was significantly higher than the $60.82 \%$ recorded in TL soil at this stage. The apparently high bulk density recorded with $\mathrm{M}_{0}$ can be attributed to the fact that there was no input of cattle-cud mulch, thus, the level of organic matter was low.
This resulted in soil compaction and a corresponding reduction in soil pore spaces. ${ }^{36}$ Agbede et al. ${ }^{37}$ observed that the addition of organic mulch increased the organic matter content of the soil and reduced the density of the soil. This led to the apparent decreasing bulk density and a corresponding increasing total porosity as the application rate of cattle-cud mulch increased.

Table I Means of some physical properties as affected by tillage and different Cattle-cud mulch rate during the pre and post planting stages

\begin{tabular}{|c|c|c|c|c|c|c|c|c|c|c|c|c|}
\hline Treat Ment & Sand & Silt & Clay & Texture & BD & TP & Ksat & $2 \mathrm{~mm}$ & Imm & $0.5 \mathrm{~mm}$ & $0.25 \mathrm{~mm}$ & MWD \\
\hline \multicolumn{13}{|l|}{ Pre-plant } \\
\hline \multicolumn{13}{|l|}{ Tillage } \\
\hline $\mathrm{TL}$ & 79.88 & 7.5 & 12.63 & Ls & 1.06 & 60.82 & 0.28 & 3 & 17.58 & 25 & 36.83 & 0.67 \\
\hline NT & 79.7I & 7.75 & 12.54 & Ls & 0.95 & 63.84 & 0.24 & 4 & 21.33 & 26.5 & 33.5 & 0.77 \\
\hline $\operatorname{LSD}_{(0.05)}$ & NS & NS & NS & & 0.11 & 2.83 & NS & NS & 3.51 & NS & 2.77 & 0.07 \\
\hline \multicolumn{13}{|l|}{ Mulch rate } \\
\hline MO & 79.88 & 7.67 & 12.45 & Ls & 1.09 & 60.82 & 0.26 & 3.5 & 19.67 & 26.33 & 37.5 & 0.71 \\
\hline MIO & 80.21 & 7.65 & 12.13 & Ls & 0.96 & 63.42 & 0.22 & 3.5 & 19.67 & 24.67 & 33.33 & 0.72 \\
\hline M20 & 79.21 & 8.07 & 12.72 & Ls & 1.03 & 61.23 & 0.28 & 3.83 & 18 & 25.83 & 31.83 & 0.69 \\
\hline M30 & 79.88 & 7.09 & 13.03 & Ls & 0.96 & 63.85 & 0.29 & 3.17 & 20.5 & 26.17 & 38 & 0.74 \\
\hline $\operatorname{LSD}_{(0.05)}$ & NS & NS & NS & & NS & NS & NS & NS & NS & NS & 3.92 & NS \\
\hline \multicolumn{13}{|l|}{ Post-plant } \\
\hline \multicolumn{13}{|l|}{ Tillage } \\
\hline $\mathrm{TL}$ & 86.88 & 5.37 & 7.77 & Is & 1.21 & 54.33 & 0.81 & 0 & 13.33 & 26.25 & 30.42 & 0.51 \\
\hline NT & 86.36 & 4.87 & 8.77 & Ls & 1.27 & 52.15 & 0.82 & 0 & 11.25 & 27.33 & 29.92 & 0.49 \\
\hline $\operatorname{LSD}_{(0.05)}$ & NS & NS & NS & & NS & NS & NS & NS & NS & NS & NS & NS \\
\hline \multicolumn{13}{|l|}{ Mulch rate } \\
\hline MO & 87.03 & 4.7 & 8.27 & Ls & 1.27 & 52.07 & 0.84 & 0 & 12 & 28.5 & 27.5 & 0.49 \\
\hline MIO & 86.36 & 5.37 & 8.27 & Ls & 1.22 & 53.95 & 0.67 & 0 & 12.5 & 23.33 & 30.67 & 0.48 \\
\hline M20 & 85.69 & 5.37 & 8.93 & Ls & 1.23 & 53.48 & 0.81 & 0 & 12.83 & 28.17 & 30 & 0.52 \\
\hline M30 & 87.41 & 5.03 & 7.61 & Ls & 1.23 & 53.47 & 0.94 & 0 & 11.83 & 27.17 & 32.5 & 0.5 \\
\hline $\operatorname{LSD}_{(0.05)}$ & NS & NS & NS & & NS & NS & NS & NS & NS & NS & NS & NS \\
\hline
\end{tabular}

$M_{0}$, mulch at 0 tonnes/ha; $M_{10}$, mulch at 10 tonnes/ha; $M_{20}$, mulch at 20 tonnes/ha; $M_{30}$, mulch at 30 tonnes/ha; Ls, loamy sand; BD, bulk density; TP, total porosity; Ksat, saturated hydraulic conductivity; MWD, mean weight diameter; LSD, least significant difference

Hydraulic conductivity: The hydraulic conductivity, Ksat of Tilled (TL) and No Tilled (NT) soils had statistically similar. The Ksat recorded in soils treated with the different rates of cattle-cud digester were not significantly different from each other. At both stages of soil study (Table 1), Ksat recorded with 0 t/ha cattle-cud digester $\left(M_{0}\right)$ application rate was apparently lower than that of 30t/ha cattle-cud mulch $\left(\mathrm{M}_{30}\right)$ application rate with the general trend suggesting an increase in Ksat with increase in cattle cud digester rates. This is translated from the effect of cattle cud mulch on bulk density and porosity stated earlier. Since soil pore spaces are the conducting channels through which water flows through the soil..$^{38}$ Therefore, the apparent increase in Ksat with increase in the application rate of cattle-cud mulch can be explained by the reduction in bulk density and increase in total porosity, which increased the rate of water flow through the soil as the application rate of the mulch increased.

Mean weight diameter: At the pre-planting stage, cattle cud mulch rate had a significant effect on aggregate sizes as observed in $0.25 \mathrm{~mm}$
(Table 1), in which $M_{30}$ rate showed significantly higher $0.25 \mathrm{~mm}$ aggregate size $(38 \mathrm{~g})$ than those of $\mathrm{M}_{20}(31.83 \mathrm{~g})$ and $\mathrm{M}_{10}(33.33 \mathrm{~g})$. Apparently higher MWD were observed among soils with higher rates of cattle cud digester treatments, though there were no significant effect of cattle cud digester rates on MWD throughout the soil study.

Soil pH and electrical conductivity: At both stages, soil $\mathrm{pH}$ and electrical conductivity were not significantly affected by tillage and cattle-cud mulch rate. Soil reactions were generally strong acid (between pH 5.1 and 5.5) (Table 2).

Organic matter, total nitrogen and available phosphorus: There was a significant effect of mulch rate on organic matter content at the pre-plant stage. Available phosphorus concentrations were generally high $\left(>25 \mathrm{mg} \mathrm{kg}^{-1}\right)$ but were not significantly affected by the cattle-cud digester rate. Apparent considerations at the pre and mid- plant stages however showed available $\mathrm{P}$ to increase as the rate of application of cattle-cud mulch increased. Organic matter and available $\mathrm{P}$ were 
observed to apparently increase with increasing rates of cattle-cud digester application because of the increase in organic matter input from the cattle-cud mulch, which in turns increased the available $\mathrm{P}$ content of the soil. ${ }^{39}$

Table 2 Means of some chemical properties as affected by tillage and Cattle-cud mulch rate during the pre and post planting stages

\begin{tabular}{|c|c|c|c|c|c|c|c|c|c|c|c|c|c|}
\hline Treatment & pH & EC & OM & $\mathbf{T N}$ & Av.P & $\mathrm{Ca}$ & Mg & $\mathrm{Na}$ & $\mathbf{K}$ & TEB & EA & ECEC & BS \\
\hline \multicolumn{14}{|l|}{ Pre-plant } \\
\hline \multicolumn{14}{|l|}{ Tillage } \\
\hline $\mathrm{TL}$ & 5.28 & 0.07 & 3.13 & 0.08 & 62.77 & 9.04 & 2.37 & 0.05 & 0.09 & 11.55 & 1.91 & 13.46 & 85.04 \\
\hline NT & 5.24 & 0.06 & 3.09 & 0.08 & 55.6 & 8.18 & 2.19 & 0.05 & 0.1 & 10.53 & 1.87 & 12.38 & 83.75 \\
\hline $\operatorname{LSD}_{(0.05)}$ & NS & NS & NS & NS & NS & NS & NS & NS & 0.01 & NS & NS & NS & NS \\
\hline \multicolumn{14}{|l|}{ Mulch rate } \\
\hline Mo & 5.24 & 0.06 & 2.96 & 0.08 & 50.88 & 8.2 & 2.32 & 0.05 & 0.1 & 10.66 & 1.87 & 12.53 & 83.82 \\
\hline MIO & 5.25 & 0.09 & 3.6 & 0.09 & 60.55 & 9 & 2.37 & 0.06 & 0.1 & 11.53 & 1.9 & 13.43 & 84.56 \\
\hline M20 & 5.36 & 0.06 & 3.04 & 0.07 & 63.55 & 9.32 & 2.4 & 0.05 & 0.1 & 11.86 & 1.9 & 13.74 & 85.66 \\
\hline M30 & 5.19 & 0.06 & 2.84 & 0.07 & 61.77 & 7.93 & 2.03 & 0.05 & 0.1 & 10.11 & 1.88 & 11.99 & 83.54 \\
\hline $\operatorname{LSD}_{(0.05)}$ & NS & NS & 0.47 & NS & NS & NS & NS & NS & NS & NS & NS & NS & NS \\
\hline \multicolumn{14}{|l|}{ Post-plant } \\
\hline \multicolumn{14}{|l|}{ Tillage } \\
\hline $\mathrm{TL}$ & 5.5 & 0.76 & 3.02 & 0.08 & 42.97 & 9.76 & 2.62 & 0.06 & 0.09 & 12.52 & 2.13 & $|4.4|$ & 87.01 \\
\hline NT & 5.48 & 0.09 & 3.23 & 0.08 & 45.02 & 9.04 & 2.57 & 0.06 & 0.1 & 11.76 & 1.77 & 13.52 & 86.91 \\
\hline $\operatorname{LSD}_{(0.05)}$ & NS & NS & NS & NS & NS & NS & NS & NS & 0.01 & NS & NS & NS & NS \\
\hline \multicolumn{14}{|l|}{ Mulch rate } \\
\hline MO & 5.47 & 0.07 & 3.07 & 0.08 & 48.69 & 10 & 2.62 & 0.07 & 0.1 & 12.79 & $\mathrm{I} .84$ & 14.59 & 87.59 \\
\hline MIO & 5.52 & 0.09 & 2.95 & 0.07 & 42.75 & 9.06 & 2.55 & 0.06 & 0.1 & 11.77 & 2.34 & 13.6 & 86.36 \\
\hline M20 & 5.48 & $\mathrm{I} .44$ & 3.24 & 0.08 & 41.04 & 9.26 & 2.62 & 0.06 & 0.09 & 12.03 & 1.8 & 13.83 & 87.18 \\
\hline M30 & 5.5 & 0.08 & 3.24 & 0.08 & 43.51 & 9.25 & 2.59 & 0.07 & 0.09 & 11.99 & I.84 & 13.83 & 86.7 \\
\hline $\operatorname{LSD}_{(0.05)}$ & NS & NS & NS & NS & NS & NS & NS & NS & NS & NS & NS & NS & NS \\
\hline
\end{tabular}

$M_{0}$, mulch at 0 tonnes/ha; $M_{10}$, mulch at 10 tonnes/ha; $M_{20}$, mulch at 20 tonnes/ha; $M_{30}$, mulch at 30 tonnes/ha; Ls, loamy sand; EC, electrical conductivity; TN, total nitrogen; Av.P, available phosphorus; Ca, calcium; Mg, magnesium; $\mathrm{Na}$, sodium, K; potassium, TEB, total exchangeable bases; EA, exchange acidity; ECEC, effective cation exchange capacity; BS, base saturation; LSD, least significant difference

Exchangeable cations: Table 2 showed that there is no significantly effect of cattle cud mulch on the concentration of exchangeable Calcium, Magnesium, Potassium and Sodium. Generally, exchangeable calcium was the most dominant basic cation, followed by Magnesium and then Potassium and Sodium in that order. Total exchangeable bases, exchange acidity, effective cation exchange capacity and base saturation were mostly not significantly affected by cattle cud mulch rate. Exchangeable Potassium was the only cation affected by tillage in the study with notill plots having higher amounts than the tilled plots. The concentrations of exchangeable bases $(\mathrm{Ca}$, $\mathrm{Mg}, \mathrm{K}$ and $\mathrm{Na}$ ) were not significantly affected by cattle-cud mulch rates and the concentrations obtained did not follow a regular pattern for it to be attributed largely to the effect of the applied cattle-cud mulch due to the variation in native soil concentrations of these basic cations. Though there were no significant effect of mulch rate on exchange acidity, apparent considerations show lower exchange acidity values for $M_{20}$ and $M_{30}$ against the figure observed for $M_{0}$ and $\mathrm{M}_{10}$. At the harvest stage, $\mathrm{M}_{20}$ and $\mathrm{M}_{30}$ also recorded exchange acidity values that were lower than that of $M_{10}$ (Table 2). The apparent decrease in soil acidity with increase in the rate of cattle-cud digester found in the study could be attributed to the efficacy of the cattle-cud in reducing soil acidity.

\section{Tuber yield of sweet potato under different tillage and cattle-cud mulch rates}

Tilled soils had tuber girth, tuber length and higher yield. However, these differences were not significant. The addition of cattle cud mulch significantly affected the tuber girth and tuber length of sweet potato as shown in Table 3 . The highest tuber girth of potato $(19 \mathrm{~cm})$ was obtained with $M_{30}$ which was significantly higher than those of $\mathrm{M}_{10}$ and $\mathrm{M}_{20}$, which recorded tuber girths of 14.75 and $13.0 \mathrm{~cm}$, respectively. Similarly, $\mathrm{M}_{30}$ produced the highest tuber length which was equal with that of $M_{20}$ but significantly higher than that of $M_{10}$. There was a general trend showing increase in yield parameters of sweet potatoes with increase in the quantity of cattle-cud mulch applied. This can be traced to the increased input of soil nutrient from the applied mulch. ${ }^{39}$ However, other yield parameters did not give significant results probably, owing to a similar non-significant difference in basic cations (soil nutrients) observed with different cattle-cud mulch rates in this study. 
Table 3 Performance of cross validation of rain water use and potato biomass yields

\begin{tabular}{lllll}
\hline \multirow{4}{*}{ Yield variables } & \multicolumn{4}{c}{ Mulch rates } \\
\cline { 2 - 5 } & $\mathbf{M}_{0}$ & $\mathbf{M}_{10}$ & $\mathbf{M}_{20}$ & $\mathbf{M}_{30}$ \\
\hline RWUE & 1.73 & 0.99 & 1.35 & 2.38 \\
Tuber Girth cm & 13.9 & 14.74 & 16.99 & 19 \\
Tuber Length cm & 18.32 & 16.06 & 18.76 & 21.07 \\
Marketable size & 28.33 & 16.17 & 23.83 & 32.33 \\
Non Marketable size & 28.5 & 15.17 & 18.83 & 27.83 \\
No. of Tuber & 56.83 & 31.33 & 42.67 & 60.5
\end{tabular}

RWUE, rain water use efficiency; $M_{0}$, mulch at 0 tonnes $/$ ha; $M_{10}$, mulch at 10 tonnes/ha; $M_{20}$, mulch at 20 tonnes/ha; $M_{30}$, mulch at 30 tonnes/ha

For the rainwater use efficiency (RWUE), no particular treatment was said to be superior to the other as there were no significant differences between them. It was not significantly affected by cattlecud mulch rate, though apparent considerations show that the highest rain water use efficiency of $2.38 \mathrm{~kg} \mathrm{ha}^{-1} \mathrm{~mm}^{-1}$ was recorded under $\mathrm{M}_{30}$ and was followed by that of $\mathrm{M}_{0}\left(1.73 \mathrm{~kg} \mathrm{ha}^{-1} \mathrm{~mm}^{-1}\right)$. Tilled soils showed higher rain water use efficiency than no-till soils and this translates to the higher tuber girth and length observed in tilled soils.

Effect of tillage practices and cattle-cud mulch rates on nutrient loss due to the harvesting of sweet potatoes

Tillage practices significantly affected the concentration of available $\mathrm{P}$ and exchangeable $\mathrm{Ca}$ lost due to the harvesting of sweet potatoes. In both cases, higher concentrations were observed in TL soils $(0.91 \mathrm{mg}$ $\mathrm{kg}^{-1}$ available $\mathrm{P}$ and $1.51 \mathrm{cmol} \mathrm{kg}^{-1}$ exchangeable $\mathrm{Ca}$ ) than in NT soils $\left(0.58 \mathrm{mg} \mathrm{kg}^{-1}\right.$ available $\mathrm{P}$ and $1.13 \mathrm{cmol} \mathrm{kg}^{-1}$ exchangeable Ca) (Table 4). Tilled soils which had higher values of RWUE reflecting in the yield of potato also had higher amounts of nutrients (TN, AvP, Ca, $\mathrm{Mg})$ lost due to harvesting.
Table 4 Loss of nutrient elements at different rates of cattle cud mulch

\begin{tabular}{lllll}
\hline \multirow{2}{*}{ Measured variables } & \multicolumn{4}{c}{ Rates of cattle cud mulch } \\
\cline { 2 - 5 } & $\mathbf{M}_{0}$ & $\mathbf{M}_{10}$ & $\mathbf{M}_{20}$ & $\mathbf{M}_{30}$ \\
\hline RWUE & 1.73 & 0.99 & 1.35 & 2.38 \\
$\mathrm{NL}_{\mathrm{TN}}$ & 0.3 & 0.29 & 0.2 & 0.27 \\
$\mathrm{NL}_{\mathrm{AVP}}$ & $0.7 \mathrm{I}$ & 0.67 & 0.88 & 0.72 \\
$\mathrm{NL}_{\mathrm{Ca}}$ & 1.55 & 1.29 & 1.29 & 1.14 \\
$\mathrm{NL}_{\mathrm{Mg}}$ & 3.34 & 2.82 & 2.9 & 2.9 \\
$\mathrm{NL}_{\mathrm{K}}$ & 1.37 & 1.36 & 1.27 & 1.24 \\
$\sum \mathrm{NL}$ & 7.27 & 6.43 & 6.54 & 6.27 \\
$\mathrm{Yield}_{\text {(NL) }}$ & 6.23 & 2.29 & 3.33 & 4.37 \\
\hline
\end{tabular}

RWUE, rain water use efficiency; $\mathrm{NL}_{\mathrm{TN}}$, total nitrogen lost to harvesting; $\mathrm{NL}_{\text {AVP }}$, available phosphorus lost to harvesting; $\mathrm{NL}_{\mathrm{Ca}}$, calcuim lost to crop harvesting; $\mathrm{NL}_{\mathrm{Mg}}$, magnesium lost to crop harvesting; $\mathrm{NL}_{\mathrm{K}}$, potassium lost to crop harvesting; $\sum \mathrm{ER}_{(\mathrm{NL})}$, summation of nutrient lost to crop harvesting; $M_{10}$, mulch at 10 tonnes/ha; $M_{20}$, mulch at 20 tonnes/ha; $M_{30}$, mulch at 30 tonnes/ha

There were no significant effect of cattle cud mulch rate on the amount of total $\mathrm{N}$, available $\mathrm{P}$, exchangeable $\mathrm{Ca}, \mathrm{Mg}, \mathrm{Na}$ and $\mathrm{K}$ lost during the harvesting of sweet potatoes (Table 4). However, the highest amounts of these nutrients were lost under $\mathrm{M}_{0}$ and the trend decreased as the rate of cattle-cud mulch increased, leading to $M_{30}$ with the lowest nutrient losses. $\mathrm{SARE}^{40}$ reported that organic matter is able to hold on to cations in a way that keeps them from leaching deep into the subsoil when water moves through the topsoil. Considering the summation of nutrient lost during harvest, the lowest value was observed in $\mathrm{M}_{30}$ which gave higher RWUE and yield of potato.

Figure 3 shows the results of rain water use, nutrients loss and yield to soil loss due to harvesting. As can be observed from the figure, there was no significant change in the use of rain water use between tilled and the untilled plots in the field which can be explained by the same level of pore continuity attributed to the cattle cud application. This means that application of cattle cud has strengthened the tortuous configurations expected of untilled field that was detrimental to crop.

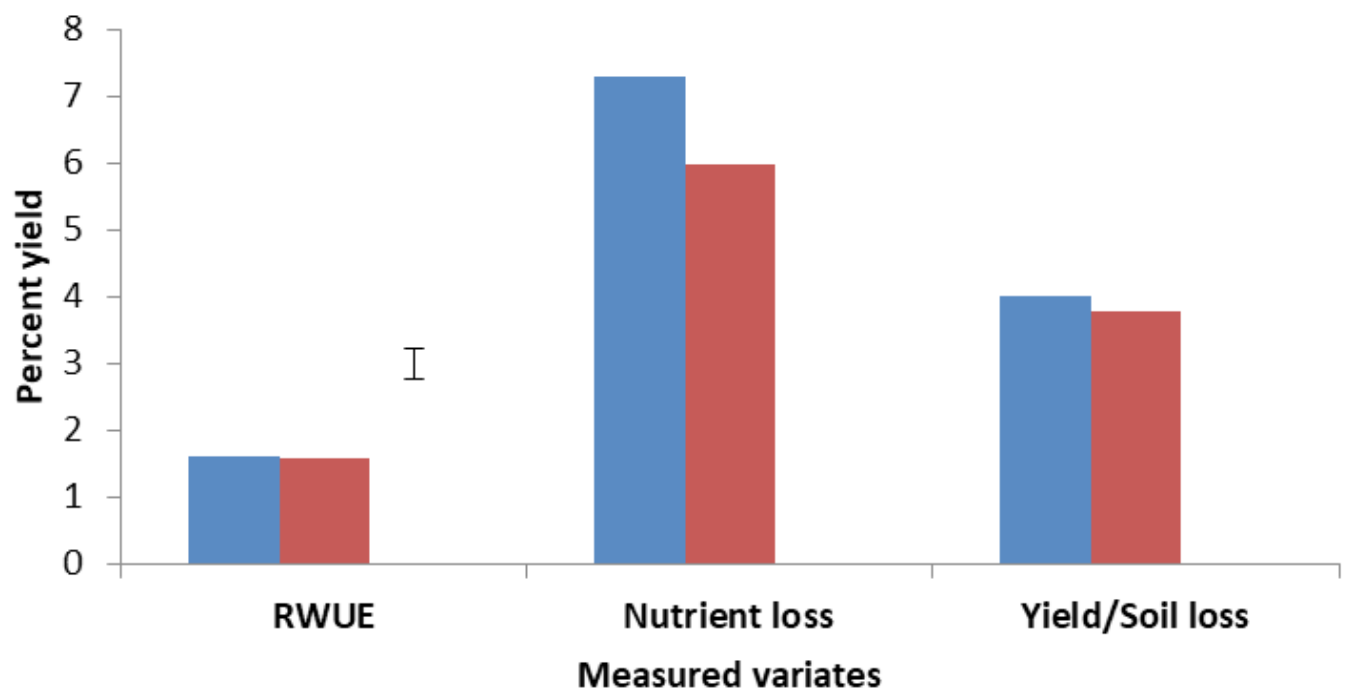

Figure 3 Percent rain water use, nutrient loss and yield under tilled and untilled plots. 
The field average nutrients loss is considerably lower in untilled plots than the tilled plots recommended for easy of plant root penetration for proper crop growth and development in the Ultisol. The spatial variabilities in these properties, which might have a negative effect on the biomass yield to soil loss performance was not significantly different between the two tillage methods.

\section{Effect of tillage-mulch combination on nutrient enrichment of the soil in Uyo}

Mean nutrient enrichment is presented in Table 5. The highest total nitrogen enrichment ratios were obtained under soils that were tilled and mulched at 30 and $20 \mathrm{tha}^{-1}$, followed by soils that were not tilled but mulched at $10 \mathrm{tha}^{-1}$. Generally, soils that were not tilled but mulched gave lower total $\mathrm{N}$ enrichment ratios and the least of it was obtained in soils that was neither tilled nor mulched $\left(\mathrm{NTM}_{0}\right)$. The highest enrichment ratios of available $\mathrm{P}$ were obtained under tilled soils that were mulched at the rate of 20 and $10 \mathrm{tha}^{-1}$. Lower nutrient enrichment ratios were obtained under no till with the least being recorded with no till and no mulch. For calcium, magnesium and potassium, soils that were tilled and mulched gave a higher enrichment ratios compared with those of no till and mulch, though there was no consistent order with regards to the rate of mulch applications. The highest RWUE value was obtained in tilled plots with mulch at 30ton/ha which also gave the highest yield of sweet potato.

Table 5 Mean effect of Tillage-mulch combination on nutrient enrichment of the soils in Uyo

\begin{tabular}{|c|c|c|c|c|c|c|c|c|}
\hline Mulch rate & RWUE & ERTN & ERAVP & ERCa & ERMg & ERK & $\sum \operatorname{ER}(\mathbf{M} *)$ & Yield \\
\hline & Untilled & & & & & & & \\
\hline 0 & 2.27 & I & 0.68 & 1.4 & 0.99 & 0.86 & 4.93 & 3.87 \\
\hline 10 & 0.98 & 2.21 & 0.87 & 1.89 & 1.4 & 0.85 & 7.22 & 1.67 \\
\hline 20 & 1.15 & 1.02 & 0.73 & 1.73 & 1.28 & 0.84 & 5.6 & 1.96 \\
\hline 30 & 1.98 & 1.16 & 1.07 & 1.85 & 1.19 & 0.86 & 6.13 & 3.37 \\
\hline \multirow[t]{2}{*}{$\operatorname{LSD}(0.05)$} & NS & 0.248 & 0.177 & 0.065 & 0.08 & 0.552 & & NS \\
\hline & Tilled pl & & & & & & & \\
\hline 0 & 1.19 & 1.51 & 1.08 & 2.9 & 1.57 & 0.95 & 8.01 & 2.04 \\
\hline 10 & 0.99 & 1.48 & 1.72 & 2.01 & 1.48 & 0.85 & 7.54 & 1.69 \\
\hline 20 & 1.54 & 2.53 & 1.59 & 2.44 & 1.28 & 0.94 & 8.78 & 2.63 \\
\hline 30 & 2.78 & 2.62 & 1.19 & 1.91 & 1.47 & 0.93 & 8.12 & 4.74 \\
\hline LSD (0.05) & NS & 0.248 & 0.177 & 0.065 & 0.08 & 0.552 & & NS \\
\hline
\end{tabular}

RWUE, rain water use efficiency; $\mathrm{ER}_{\mathrm{TN}}$, total nitrogen added to the soil, $\mathrm{ER}_{\mathrm{AVP}}$ available phosphorus added to the soil; $\mathrm{ER}_{\mathrm{Ca}}$, calcuim added to the soil; $\mathrm{ER}_{\mathrm{Mg}}$, magnesium added to the soil; $E_{K_{K}}$, potassium added to the soil; $\sum E R_{\left(M^{*}\right)}$, summation of nutrient added to the soil; TL, Tillage; $N T$, no till; $M_{0}$, mulch at 0 tonnes/ha; $M_{10}$, mulch at 10 tonnes/ha; $M_{20}$, mulch at 20 tonnes/ha; $M_{30}$, mulch at 30 tonnes/ha; $L S D$, least significant difference

\section{Relationships between yield of sweet potatoes and soil} properties

Positive correlations were also observed between rainwater use efficiency and Number of tubers, tuber length and tuber girth (Table 6). Number of tubers correlated significantly and positively with mean weight diameter (MWD) (Table 7). The significant and positive correlation of yield of sweet potatoes with number of tubers, tuber length occurred because both number of tubers and tuber length are components of yield. Yield components also correlated significantly and positively with rainwater use efficiency because water is essential for plant growth. ${ }^{38,41}$

Table 6 Correlations between sweet potatoes yield parameters

\begin{tabular}{llllll}
\hline & YIELD & No of tubers & Tuber length & Tuber girth & RWUE \\
\hline YIELD & $\mathrm{I}$ & & & \\
No of Tuber & $.857 * *$ & $\mathrm{I}$ & $\mathrm{I}$ & \\
Tuber Length & $.536^{* *}$ & 0.339 & $.404^{*}$ & $\mathrm{I}$ \\
Tuber Girth & $.626 * *$ & 0.373 & $.536 * *$ & $.624 * *$ & 1 \\
RWUE & $1.000 * *$ & $.857 * *$ & &
\end{tabular}

RWUE, rain water use efficiency 
Table 7 Correlations between sweet potatoes yield and some soil physical properties

\begin{tabular}{llllll}
\hline & YIELD & No of tubers & Tuber length & Tuber girth & RWUE \\
\hline Sand & -0.021 & -0.193 & 0.112 & 0.262 & -0.023 \\
Silt & 0.074 & 0.066 & 0.142 & 0.005 & 0.076 \\
Clay & -0.027 & 0.168 & -0.217 & -0.289 & -0.026 \\
Ksat & 0.227 & 0.275 & 0.126 & 0.197 & 0.228 \\
BD & -0.018 & -0.105 & 0.113 & 0.136 & -0.015 \\
TP & -0.039 & 0.066 & -0.096 & -0.152 & -0.042 \\
MWD & 0.234 & $.414 *$ & 0.026 & 0.323 & 0.232
\end{tabular}

Ksat, saturated hydraulic conductivity; BD, bulk density; TP, total porosity; MWD, mean weight diameter; RWUE, rainwater use efficiency

Yield and number of tubers of sweet potatoes increased with increase in base saturation $\left(\mathrm{r}=0.456^{*}\right.$ and $0.542^{* *}$, respectively). Tuber length correlated significantly and positively with soil $\mathrm{pH}$ (Table 8). The positive correlation of tuber length with soil $\mathrm{pH}$ is due to the fact that as soil $\mathrm{pH}$ increases from acid towards neutral, there is an increase in the availability of basic cations (soil nutrients). It can also be attributed to the favourable conditions offered to microorganisms to grow and perform their functional ecological roles which culminated in increased nutrient availability.

Table 8 Correlations between sweet potatoes yield and some soil chemical properties

\begin{tabular}{llllll}
\hline & YIELD & No of tub & Tub length & Tub girth & RWUE \\
\hline $\mathrm{PH}$ & 0.093 & 0.176 & $0.446^{*}$ & -0.094 & 0.096 \\
$\mathrm{OM}$ & -0.019 & -0.013 & -0.069 & -0.243 & -0.019 \\
$\mathrm{TN}$ & -0.121 & -0.07 & -0.028 & -0.187 & -0.122 \\
$\mathrm{AP}$ & 0.111 & 0.193 & 0.063 & 0.029 & 0.11 \\
$\mathrm{Ca}$ & -0.211 & -0.311 & -0.182 & 0.05 & -0.211 \\
$\mathrm{Mg}$ & -0.204 & -0.36 & -0.087 & -0.013 & -0.204 \\
$\mathrm{~K}$ & -0.021 & 0.077 & -0.135 & -0.385 & -0.017 \\
$\mathrm{TEB}$ & -0.212 & -0.324 & -0.166 & 0.035 & -0.213 \\
$\mathrm{EA}$ & -0.046 & -0.065 & 0.133 & 0.178 & -0.049 \\
ECEC & -0.178 & -0.296 & -0.136 & 0.059 & -0.178 \\
$\mathrm{BS}$ & $0.456^{*}$ & $0.542^{* *}$ & -0.278 & -0.193 & $-.456 *$ \\
\hline
\end{tabular}

$\mathrm{OM}$, organic matter; TN, total nitrogen; $\mathrm{AP}$, available phosphorus; TEB, total exchangeable bases; ECEC, effective cation exchange capacity; $\mathrm{BS}$, base saturation; RWUE, Rainwater use efficiency

\section{Conclusion and recommendation}

Findings from the study showed that RWUE was higher in tilled soils. This translated to the yield of potato; however, higher amounts of nutrients ( $\mathrm{TN}, \mathrm{AvP}, \mathrm{Ca}, \mathrm{Mg}, \mathrm{K}$ ) were also lost due to harvesting in tilled soils. RWUE was highest in the experimental units with the highest rate of cattle cud mulch. The nutrient enrichment of tilled soils was generally higher than those of untilled soils. The result also showed that No-tillage decreased bulk density, increased total porosity, preserved soil organic matter and promoted soil aggregate stability as well as increased the saturated hydraulic conductivity, whereas the reverse were the case with tilled soils. soil porosity and organic matter content can be increased by the addition of cattle-cud mulch which translates to the increase in the hydraulic conductivity of the soil which is relevant to the capacity of the soil to infiltrate rain water for use by plants. There was also an increase of tuber girth and tuber length as the rate of cattle-cud mulch application. In a bid to increase output in the production of sweet potato, cattle-cud mulch as a source of organic manure is recommended for use to increase the water infiltration capacity of the soil thereby leading to an efficient water use efficiency of the crops.

\section{Acknowledgments}

None.

\section{Funding}

None.

\section{Conflicts of interest}

The authors declare that there are no conflicts of interest.

\section{References}

1. Edem ID, Nkereuwem ME. Crucial roles of tuber crops and the development activities in the global food system. American Journal of Agricultural Science. 2015;2(2):42-49. 
2. Ray RC, Ravi V. Effect of time of introduction soybean into potato on the performance of potato/soybean intercrop in Jos Plateau, Nigeria. Journal of Sustainable Agricultural Environment. 2005;4(2):185-191.

3. United States Department of Agriculture - Economic, Statistics, and Marketing Information. U.S. Sweet Potato Statistics - 03001. 2010.

4. Sullen DM. Effects of color plastic mulches and row cover on the yield and quality of Sweet Potato [Ipomea batatas cv. 'Beauregard']. A published thesis of the Graduate Faculty of Auburn University, Alabama; 2010. 56 p.

5. Srinivas T. Economics of sweet potato production and marketing. In: Loebenstein G, Thottappily G, editors. The Sweet Potato. Springer, Dordrecht; 2009:235-267.

6. Reddy R, Soibam H, Ayam VS, et al. Morphological characterization of sweet potato cultivars during growth, development and harvesting. Indian Journal of Agricultural Resources, 2018;52(1):46-50.

7. Berberich T, Takagi T, Miyazaki A, et al. Production of mouse adiponectin, an anti-diabetic protein, in transgenic sweet potato plants. Journal of Plant Physiology. 2005;162:1169-1176.

8. Stathers T, Mwanga R, Carey T, et al. Everything you ever wanted to know about sweet potato: Reaching agents of change ToT manual. Topic 6: Sweet potato Production and Management. International Potato Center. Nairobi (Kenya); 2018. 33 p.

9. Ramirez GP. Cultivation harvesting and storage of sweet potato products. 2019.

10. Nedunchezhiyan M, Ray RC. Sweet potato growth, development, production and utilization: Overview. 2010.

11. Blankenagel S, Yang Z, Avramova V, et al. Generating plants with improved water use efficiency. Agronomy. 2018;8:194.

12. Grains Research and Development Corporation (GRDC). Water use efficiency. 2009.

13. Hatfield JL, Dold C. Water-use efficiency: advances and challenges in a changing climate. Frontiers in Plant Science; 2019.

14. Kar G, Kumar A. Effects of irrigation and straw mulch on water use and tuber yield of potato in eastern India. Agricultural Water Management. 2007;94(1):109-116.

15. Dvořák $P$, Tomášek $J$, Hamouz $K$, et al. Reply of mulch systems on weeds and yield components in potatoes. Plant Soil and Environment. 2015;61(7):322-327.

16. Telkar SG, Singh AK, Kant K, et al. Types of mulching and their uses for dry land condition. Biomolecule Reports; 2006.

17. Hall JB, Silver S. Nutrition and feeding of the cow-calf herd: digestive system of the cow. 2009.

18. Linn J, Hutjens M, Shaver R, et al. The ruminant digestive system. 2018

19. Khan GD, Din SU, Ramzan M, et al. Influence of tillage and mulching practices on soil physical properties under semi-arid environment Journal of Environment and Earth Science. 2014;4(9):120-124.

20. Lal R. Tillage effects on soil degradation, soil resilience, soil quality, and sustainability. Soil and Tillage Research. 1993;27:1-8.

21. Agbede TM, Olasekan AA. Tillage effects on soil properties and performance of sweet potato on an Alfisol in Southwestern Nigeria. American-Eurasian Journal of Sustainable Agriculture. 2009;3(3):561568 .

22. Climate-Data.org. Uyo climate. 2016.

23. Udosen, CE. Rainfall trends in Uyo-Akwa Ibom State and its implication on urban flooding. 2012.
24. Klute A. And Dirksen C. Hydraulic conductivity and diffusivity: Laboratory methods. Methods of soil analysis Part 1: Physical and Mineralogical Methods, $2^{\text {nd }}$ edn. American Society of Agronomy-Soil Science Society of America; 1986. 1188 p.

25. Gulser G, Candemir F. Prediction of saturated hydraulic conductivity using some moisture constants and soil physical properties. 2008.

26. Mclean EO. Soil $\mathrm{pH}$ and lime requirement. In: Page AL, Miller RH, Keeney DR, editors. Methods of Soil Analysis. Part 2, 2nd edn. Agronomy Monograph 9, American Society of Agronomy, Madison, Wisconsin, 1982. $1350 \mathrm{p}$

27. Rhoades JD. Salinity: electrical conductivity and total dissolved solids. In: Sparks DL, Page AL, Helmke PA, editors. Methods of Soil Analysis. Part 3, Soil Science Society of America and American Society of Agronomy, Madison; 1996. 1390 p.

28. Nelson DW, Sommers LE. Total carbon, organic carbon and organic matter. In: Page AL, Miller RH, Keeney DR, editors. Methods of Soil Analysis. Part 2, 2nd edition, Agronomy Monograph 9, American Society of Agronomy, Madison, Wisconsin; 1982. 1350 p.

29. Bremner JM, Mulvaney. Total Nitrogen. In: Page AL, Miller RH, Keeney DR, editors. Methods of Soil Analysis. Part 2, 2nd edition, Agronomy Monograph 9, American Society of Agronomy, Madison, Wisconsin; 1982. $1350 \mathrm{p}$

30. Kuo S. Phosphorus. In: Sparks DL, Page AL, Helmke PA, editors Methods of Soil Analysis Part 3, Soil science society of America and American Society of Agronomy, Madison, 1996. 1390 p.

31. Murphy J, Riley JP. A modified single solution method for the determination of phosphate in natural waters. Analytica Chimica Acta. 1962;27:31-36.

32. Thomas GW. Soil pH and soil acidity. pp. In: Sparks DL, Page AL, Helmke PA, editors. Methods of Soil Analysis Part 3, Soil Science Society of America and American Society of Agronomy, Madison; 1996:475-490.

33. Karlen DL, Stott DE. A framework for evaluating physical and chemical indicators of soil quality. Defining Soil Quality for a Sustainable Environment. IN: Doran JW, Coleman DC, Bezdicek DF, editors. Madison, Wisconsin, USA: Soil Science Society of America Inc; 1994;35:53-72.

34. Cogle AL, Rao KP, Yule DF, et al. Soil management for Alfisol in the semiarid tropics: erosion, enrichment rations and runoff. Soil Use and Management. 2002;18:10-17.

35. Omenihu AA, Opara-Nadi OA. Changes in a tropical Ultisol under different management systems in Southeastern Nigeria: 1. Soil physical and hydrological properties. Nigeria Journal of Soil Science. 2015;25:70 79.

36. United States Department of Agriculture. Soil health guide for educators: Bulk density/moisture/aeration. United States Department of Agriculture - Natural Resources Conservation Service, US; 2014.

37. Agbede TM, Adeyinka AO, Ogeh SJ. Effects of Chromolaena and Tithonia mulches on soil properties, leaf nutrient composition, growth and yam yield. West African Journal of Applied Ecology. 2013;21(1):15-29.

38. Hillel D. Introduction to environmental soil physics. New York: Academic Press; 2004.

39. Bot A, Benites J. The importance of organic matter: key to droughtresistant soil and sustained food production. Rome: Food and Agriculture Organization of the United Nations; 2005.

40. Sustainable Agricultural Research and Education (SARE). Why Soil Organic Matter Is So Important. 2012.

41. Barker AV, Pilbeam DJ. Hand book of plant nutrition. Boca Raton, FL: CRC Press; 2007. 